Article

\title{
Environmental Governance for the Anthropocene? Social-Ecological Systems, Resilience, and Collaborative Learning
}

\author{
Fikret Berkes \\ Natural Resources Institute, University of Manitoba, Winnipeg, MB R3T 2N2, Canada; \\ fikret.berkes@umanitoba.ca; Tel.: +1-204-474-6731
}

Received: 13 June 2017; Accepted: 11 July 2017; Published: 13 July 2017

\begin{abstract}
The Anthropocene is characterized by rapid global change, necessitating adaptive governance. But how can such adaptive governance be operationalized? The article offers a three-point argument to approach this question. First, people and environment need to be considered together, as social (human) and ecological (biophysical) subsystems are linked by mutual feedbacks, and are interdependent and co-evolutionary. These integrated systems of humans and environment (social-ecological systems) provide an appropriate unit of analysis. Second, the resilience approach deals with change in multilevel complex systems, and has stimulated much of the adaptive governance literature by addressing uncertainty and adaptation to unforeseen future changes. Third, there is a need to foster collaborative approaches to improve social and institutional learning, as for example in adaptive management, collaborative learning networks, and knowledge co-production. Collaborative learning is perhaps where further research, experimentation, and application might make a difference for operationalizing adaptive governance, with a focus on institutions, at all levels from local to international.
\end{abstract}

Keywords: social-ecological systems; complex adaptive systems; scale; self-organization; commons; resilience; adaptive management; networks; knowledge co-production

\section{Introduction}

Accelerated global environmental change, characterized most notably by climate change and rapid loss of biodiversity, has ushered in a new era. The Anthropocene marks an epoch that began when human activities started to cause significant changes in the earth's biogeochemical cycles and ecosystems [1,2]. Major changes include scarcity of critical resources, the degradation of ecosystem services and massive shifts in land use [3]. The complexity and magnitude of the problem are revealed by systematic assessments of earth's ecosystems and their ability to support human well-being [4], and the analysis of planetary boundaries that should not be transgressed [5]. But governance issues regarding these problems have received relatively little discussion in the literature [6,7]. As identified by the call for papers for this special issue, priorities include governance across levels, adaptive approaches that incorporate learning, and collaborative approaches to assist with learning in a world characterized by accelerated environmental change. Here I explore some considerations related to these priorities.

Global environmental problems do not occur in isolation but tend to be interconnected, sometimes in unexpected ways. Thus, it is useful to conceptualize the global environmental system as a complex adaptive system [8,9], one that has a number of attributes not observed in simple systems. A simple system can be adequately described using a single perspective and a standard analytical model, such as Newtonian mechanics, but a complex adaptive system cannot. Rather, complex systems can be characterized by scale effects, nonlinearities and tipping points, inherent uncertainty or unpredictability, 
self-organization, connectivity, path-dependence, and emergent properties such as resilience [10] that cannot be predicted from examining the parts of the system.

Levin argues that self-organization (where some form of overall order arises from local interactions between parts of an initially disordered system) provides a unifying principle for complex adaptive systems [8]. From a governance point of view, Young holds that connectivity and nonlinearity may be particularly important [11]. Connectivity makes it difficult to establish boundaries for regulatory frameworks; nonlinear change undermines rigid rules and calls for arrangements capable of adapting to rapid change and frequent surprises [11].

Scale is another key characteristic of complexity in human-environment systems, especially in discussions of multilevel governance. Following Gibson et al., I use the term "scale" to refer to space, time, and jurisdictional scales, and "level" to refer to a specific point along a particular scale [12]. As such, governance issues in the Anthropocene are often multilevel, cutting across the jurisdictional scale and linking decision-makers horizontally and vertically [13,14]. For example, the local perspective on biodiversity may be largely about livelihoods, the national perspective about tourism development, and the international perspective about global biodiversity conservation [15]. Each of these perspectives may be valid and important; in a complex system, there is no single "correct" perspective.

The spatial scale matters and the time scale is often critical as well. For example, co-management arrangements often require time to mature, as institutional networks develop and trust is established [16]. As well, there is the phenomenon of path-dependency. The long-term success of co-management often depends on the early experience with cooperation (or lack of it) among the parties and time's arrow cannot be reversed [17]. In interacting systems of people and environment, complex adaptive systems thinking is thus concerned with scale, nonlinearity, uncertainty, emergence, and self-organization, and governance needs to take these factors into consideration $[7,18]$.

Many of the resources and environments in question are commons (common-pool resources) in which (a) exclusion or the control of access of potential users is difficult, and (b) each user is capable of subtracting from the welfare of all other users [19]. In the 1980s and 1990s, commons researchers focused on local commons to build theory, but many of the resulting design principles for sustainable commons use seem to be pertinent at multiple levels from local to global [20]. Stern examined the degree to which the Ostrom design principles transfer to global commons, and concluded that in general they did [21]. But, the list of principles developed at the local level needed some modification and elaboration to apply to global commons. Thus, the starting point of the argument in this paper is that interacting systems of people and environment are not only complex adaptive systems, but they are to a large extent also commons, subject to many of the governance principles for the sustainable use of commons [22].

It follows that many of the governance challenges of the global environment, as a complex adaptive system, can be posed as commons problems, with emphasis on commons institutions [20,22]. As these challenges are in the context of rapid change, system dynamics become crucially important, requiring adaptive governance with feedback learning [23,24].

Adaptive governance is not a self-evident goal; it is used here as a normative concept, much the same as sustainability [3]. How can such adaptive governance be operationalized? The question has many dimensions. For adaptive governance to become operational, the characteristic(s) to be developed in the long-term must be identified, as Norton argues in the context of sustainability [3].

As the key characteristic to be developed here is the ability to deal with change in a highly uncertain world, the goal of the paper is to address operationalizing adaptive governance. I address this topic through three interrelated areas. First, systems of people and environment need to be considered together and not separately. Such social-ecological systems can be used as the unit of analysis in the context of commons institutions [25]. These social-ecological systems are complex adaptive systems and can be treated as such [24], especially in dealing with connectivity wherein the impacts of drivers may be far removed from their origins [11]. Second, the concept of resilience deals with system change, learning, and adaptation, and is therefore appropriately applicable to the analysis of scale issues and 
the adaptive in adaptive governance. As Chaffin et al. have shown, adaptive governance has largely been an outgrowth of the search for ways of managing uncertainty and complexity in social-ecological systems [7]. Third, given that many of our conventional environmental governance systems seem to lack learning capacity, there is a need to highlight and foster collaborative learning towards improving adaptive governance. The paper highlights some selected collaborative learning approaches, including adaptive management, and argues that improving practices of collaborative learning is necessary for integrative understanding towards operationalizing adaptive governance.

\section{Social-Ecological Systems and Commons Institutions}

Focusing on the ability of ecosystems to support human needs, the Millennium Ecosystem Assessment was the first comprehensive scientific stock-taking at the global level [4]. The MA examined the world's various ecosystems and the services that they provide for human well-being. Ecosystem services are defined as the benefits people obtain from ecosystems, including provisioning services (such as food and water), regulating services (such as flood control and waste assimilation), cultural services (such as recreational and spiritual values), and supporting services (such as photosynthesis and nutrient cycling) [4]. The work of the Millennium Ecosystem Assessment has been extended by IPBES, the Intergovernmental Science-Policy Platform on Biodiversity and Ecosystem Services, and some of these terms and concepts are under revision $[26,27]$.

The examination of the relationship between ecosystem services and human well-being can be carried out in a variety of ways, including the approaches used in MA [4] and in a variety of other studies. The approach we have been using starts by applying the term social-ecological systems as an integrated perspective of humans-in-nature, and considers these integrated systems of humans and environment as the basic unit of analysis $[18,28]$. The intertwined nature of social-ecological systems means that they operate within the biosphere as embedded parts of it, and co-evolve with and depend on it [24]. The social (human) and ecological (biophysical) subsystems each consist of multiple levels. For example, a small watershed is part of a river system which may in turn be part of a larger watershed. Similarly, a set of institutions may be nested in one another, from local resource user associations to regional and national ones. In the Spanish huertas analyzed by Ostrom, institutions of irrigators were organized on the basis of three or four nested levels that corresponded to local, regional, and national governmental jurisdictions [20].

The social subsystem incorporates economics, politics, history, and ethics (including worldviews). It probably does not include health, as health is often a characteristic of the full social-ecological system-indigenous Australians had it right all along: "healthy country, healthy people" [29]. Social-ecological health also captures Aldo Leopold's land health [30]. Here we use the term social-ecological, rather than socio-ecological, because social-ecological emphasizes that the two subsystems are equally important, whereas socio- is a modifier, implying a less than equal status of the social subsystem.

Thus, social-ecological systems are integrated complex adaptive systems in which social and ecological subsystems are coupled and interdependent, each a function of the other, expressed in a series of mutual feedback relationships [18,31]. The links between the social and the ecological subsystem may include knowledge, such as local and indigenous knowledge held by resource-based communities, or scientific knowledge held and used by government resource managers. Institutions, which are the rules and norms that mediate how humans interact with one another and the environment, or rules-in-use, provide a key link between the social group and its resource base [20]. Governance provides a broad and comprehensive link between social and ecological subsystems, as it includes management and policy levels [32].

The social-ecological systems approach considers institutions and governance as an integral part of the ecosystem, not separate from it. For example, the governance of a fishery cannot be separated from the fish, as management affects the supply of fish, and the fish population levels in turn shape the management measures that may be taken. Connectivity may be complex. A particular social-ecological system, for example, the sea urchin fishery in Chile, may suffer the impacts of a driver far removed 
spatially, for example, the sushi market demand in Japan [33] - a phenomenon that Young refers as telecoupling [11]. Similarly, the ecosystem services provided by a forest are profoundly influenced by the institutions that govern their use. The forest may provide provisioning services such as fuelwood and non-timber forest products for a local community, or regulating services such as flood control for an urban area, or cultural services such as recreation, or supporting services such as photosynthesis and nutrient cycling for the larger ecosystem. Often, a forest is managed to provide not one kind of service but a mix of ecosystem services.

The use of a commons, such as the forest in the example above, under open-access or free-for-all conditions, almost always leads to unsustainable outcomes, as is well-known in the commons literature. Commons can be used under private property or state-property or common-property regimes, or mixes thereof. All three regimes, as well as mixed regimes such as co-management [34], are theoretically viable [22,35]. State-property relies on government regulations and top-down decision-making. Private property relies on market mechanisms and makes sense for certain kinds of resources such as agricultural land, in which the owner can control access and internalize the costs of subtractability [19]. Common-property makes sense for resources and ecosystem services which are, by their nature, shared. The sustainable use of ecosystem services for human well-being from such shared resources often requires institutions for collective action and collaborative decision-making [20]. Reliance on top-down state management or purely market solutions tends not to work.

Institutions for commons governance are not found at just one level but at multiple levels of organization from local to global, and these levels tend to be linked. Some of these levels and their linkages seem to be understudied [6,36]. Because of the high profile of global environmental issues in the Anthropocene, the planetary level has received a great deal of attention [2,5], often to the neglect of other levels of organization. This creates a problem in understanding linkages, as institutions at various levels cannot function in isolation but need to work together in a coordinated way [22]. Where connectivity in the social-ecological system involves telecoupling, as in climate change where greenhouse gases generated mainly at mid-latitudes results in thinning Arctic sea-ice, regulatory coordination can be even more problematic [11].

For example, international treaties are probably necessary but insufficient for the reduction of greenhouse gases, even if the major nations involved cooperated and coordinated fully. Nor it is possible to reduce greenhouse gases simply by trying to regulate emissions at the national level and/or using market mechanisms by introducing carbon pricing. New rules, incentives, and practices leading to greenhouse gas reduction are needed at local and regional levels as well. Such action may include, for example, the use of renewable energy, appropriate urban design, increased use of renewable energy, policies to encourage more extensive use of public transportation, making residential and industrial heating more efficient, stimulating energy-efficiency in industrial production, and use of sustainable agriculture and sustainable forestry principles. National policies to develop and use renewable energies need to be supported by municipal level regulations and incentives to facilitate them and by the willingness of citizens to use them [37]. Solutions for sustainability need to engage institutions at multiple levels, from local to global.

\section{Social-Ecological System Resilience and Scale}

The implication of these considerations is that promoting governance for sustainability requires multilevel, integrative, and interdisciplinary research and action, with attention to both the ecological and the social subsystems. The resilience of the social-ecological system is an important consideration: it refers to the ability of the system to respond to stresses and shocks while maintaining system identity and main system functions [38]. A resilient social-ecological system has the ability to respond to perturbations while preserving the functioning and identity of the system. In general, resilient systems have the ability (1) to absorb shocks and stresses, (2) to self-organize, and (3) to learn and adapt [10].

Thus, resilience thinking introduces a dynamic element into sustainability and helps operationalize the adaptive element of adaptive governance. In practical terms, resilience is about 
options and flexibility is forward-looking. For example, a resilient social-ecological system may have a high diversity of landscapes, native species, and crop species and varieties, as well as a diversity of economic opportunities and livelihood options for its inhabitants. Ostrom's notion of crafting institutions is relevant here: new institutions come about more readily if there is a diversity of existing institutions [35]. Such diversity and abundance of options provide a built-in ability to buffer change or to adapt to change. Nevertheless, until change actually occurs, there is no easy way to determine beforehand if the system can cope with that change or adapt.

The notion of ecological resilience started with Holling in 1973 [39]; however, social-ecological resilience did not become a commonly used concept until the 2000s [40]. In recent years, resilience has become a central concept in sustainability science because it is probably the most commonly used theory of social-ecological change, in a variety of contexts from international development to climate change adaptation [40,41]. In fact, Brown defines resilience broadly as the ability to successfully deal with change [42]. Conceptualizing resilience as an ability is a useful way to deal with change, adaptation, and transformation.

A relatively small perturbation in a social-ecological system typically triggers short-term or coping responses. However, if this coping or absorptive capacity is exceeded, individuals and communities would then exercise their adaptive resilience. Long considered the core of resilience, adaptive capacity refers to the ability of the social-ecological system to learn and to adjust its responses to the impacts of external drivers and internal change. The system undergoes change while still retaining its system identity-function, structure and feedbacks [38]. However, if the changes are so large that they overwhelm the adaptive capacity of the system, the response is no longer incremental but it becomes transformative. The system no longer retains its identity; it has been transformed. Such changes involve shifts in the nature of the system, such as when a household adopts a new way of making a living, or when a coastal region may move from a fishing economy to a tourism-based economy [43].

Transformative changes may involve institutional change, technological innovation, behavioral shifts, and cultural change. They often entail a questioning of values, beliefs, and assumptions [44]. Transformability is understood as the ability to create a fundamentally new system when ecological, social, and economic conditions of the old system are no longer tenable [45]. Brown considers absorptive capacity, adaptive capacity, and transformative capacity as the three dimensions of social-ecological resilience [42]. As Béné et al. point out “... resilience emerges as the result of not one but all three of these capacities, each of them leading to different outcomes: persistence, incremental adjustment or transformational responses," and these different responses can be linked to an intensity continuum of shocks and stresses [44:601]. In the examples above, we are referring to social-ecological resilience [28], as resilience is a property of the system as a whole, and not only of the social or the ecological subsystem alone.

Social-ecological resilience thinking recognizes the nested character of social-ecological systems, and introduces the notion of panarchy (embedded scales = pan-archies) to deal with the challenge of connectivity across the various levels of the system [10]. Initially modelled after the dynamics of boreal forests, each cycle is depicted as a reclining figure eight, representing the adaptive cycle of the forest as it goes through stages of growth, maturity, disturbance/release, and reorganization. Essentially, Gunderson and Holling were arguing that social-ecological system dynamics can be approached heuristically as nested sets of adaptive cycles, with dynamic interactions occurring among large (and therefore slow) cycles and small (and therefore fast) cycles [10].

This model works well with many ecological systems but has not been taken up by many scholars for the analysis of institutions or social-ecological systems in general [46]. There may be several reasons for this. For one, social scientists tend to be wary of deterministic models, emphasizing agency instead [47]. For another, panarchy assumes nested systems where the levels are distinct, but in real life they often are not. For example, a monolithic national level hides the fact that they often are agencies and groups within the national level that may well have very different kinds of interactions with other levels [48]. As well, a particular change process does not necessarily involve all levels and may actually skip some. For example, 
pandemics can move swiftly across levels while skipping some, going from individuals to communities and then directly to outbreaks far away, or they may jump laterally from one set of communities to another set on a different continent [49].

Much of the literature dealing with linkages in multilevel social-ecological systems does not use the panarchy idea. Rather, the literature often uses polycentric systems characterized by multiple and overlapping jurisdictions at different levels [50]. Polycentric systems often have several governing authorities, rather than a single one. It has been argued that these types of systems are well suited for the governance of dynamic natural resources due to their adaptability, and for their self-organizing and learning capacity $[23,51]$.

As well, the literature uses the notion of interplay of levels, with horizontal and vertical linkages [13], often in the form of networks. For example, in the Arctic small whale management example of Armitage et al. [34], horizontal and vertical linkages indicate how the co-management system is structured. In the Swedish biosphere reserve case of Olsson et al. [52], a sketch of the main networks indicates the structure of collaborative problem solving. The choice of specific linkages and network structures is significant for showing how learning-by-doing can be approached toward adaptive governance.

\section{Collaborative Approaches toward Adaptive Governance}

Complex global environmental problems cut across governance levels, and therefore a governance approach that relies on demarcations by jurisdiction or sector is not a good fit. Furthermore, accelerated global change in the Anthropocene calls for approaches that are problem-oriented, flexible, and that involve experimenting with policies and reflecting on the consequences. In addition to considerations for democratic decision-making, there are a number of reasons for using collaborative approaches, including the inadequacy of conventional science and management in the face of uncertainty, and the increasingly wicked nature of global environmental issues that makes the role of the objective expert almost obsolete [53].

Conventional science and environmental management are appropriate when uncertainty is low and controllability is high (as in laboratory systems) and the rate of change is slow. As conventional science and management are based on assumptions of equilibrium and controllability, conditions of high uncertainty and low controllability call for some other approach—adaptive management [54]. Adaptive management relies on experimentation and learning, and may be best thought of as a cycle similar to planning cycles used in urban planning, parks planning, and other areas.

Adaptive management ideas have been applied to resource and environmental co-management, the idea of sharing management power and responsibility between the government and local resource users $[48,55]$. Co-management has a time dimension, as sharing power and responsibility requires many adjustments and time to mature [16]. Such time-tested co-management that incorporates learning becomes adaptive co-management that combines learning and collaboration features [34].

Adaptive management, adaptive governance, and adaptive co-management are about ongoing processes, not a search for some optimal solution to one problem. Adaptation is a problem-solving process, whereby priority is given to communication, perspective sharing, social learning, negotiation, and the development of adaptive collaborative strategies for moving forward. An ongoing planning cycle makes it possible to respond to changing conditions, and allows for learning to be captured and incorporated into subsequent rounds of problem-solving, especially in situations in which uncertainty is high.

Ludwig extends the uncertainty argument further by pointing out that many of our global environmental problems such as climate change fall into the category of wicked problems, those with no definitive formulation, no stopping rule, and no test for a solution [53]. Such problems do not lend themselves to resolution by the conventional scientific approach of defining objectives, devising experiments to address the problem, collecting relevant data, and making decisions based on these 
data. That is because there is too much uncertainty and targets keep shifting, making it necessary to keep redefining the issues.

Further, these wicked problems tend to be societal problems, rather than technical problems. They cannot be separated clearly from issues of values, equity, and social justice. Thus, the notion of value-free science is no longer relevant, and there no longer is an objective expert who can be relied upon to deliver a solution. Hence, a new kind of approach must be created through a process whereby researchers, managers, and stakeholders together define and redefine the questions, use a mix of study approaches, and deliberate on the relevant evidence [53]—the essence of sustainability science [56].

There are various kinds of collaborative or cooperative approaches toward adaptive governance. To the extent that a diversity of actors is involved in the process (rather than only experts), adaptive management is one of them. Co-management and adaptive co-management are, by definition, collaborative approaches. There are many kinds of adaptive collaborative strategies that involve or facilitate learning-by-doing, experimenting with policy options and reflecting on the outcomes. Here I mention two of them: knowledge co-production and use of problem-solving collaborative networks.

Knowledge co-production has many definitions; for our purposes, it is the collaborative process of bringing a plurality of knowledge sources and types together to address a defined problem [57]. It can be expressed as the multiple evidence base approach [58], emphasizing the advantages of combining different kinds of knowledge to approach problems. It may involve participatory research-learning together to co-produce knowledge. More broadly, it may involve emergent dialogue, whereby the meaning and value of information is co-created among the various interests.

The examples used by Armitage et al. are cases of combining indigenous knowledge with western science to solve co-management problems in the Canadian North [57]. The James Bay, Quebec, Canada, co-management case is similar in that it involves combining local indigenous and scientific knowledge to understand the impacts of hydroelectric development on resources and the environment. In this particular case, however, successive cycles of knowledge co-production resulted in broadening the scope of collaborative problem solving, going from local resource issues to understanding ecosystem processes, and from involving a small group of observers to multiple actor processes [59].

Learning-as-participation seems to be the key mechanism, resulting in increasing levels of trust, along with the ability to tackle increasingly more complicated and larger-scale problems [55]. Knowledge co-production is, of course, not restricted to indigenous knowledge cases. In Lake Racken, Sweden, a key individual in the community detected acidification before the government monitoring program started. Combining local observations with science, the community moved from the acidification issue to lake ecosystem management, restoring and managing viable populations of crayfish and trout [60]. Lake Racken fishing associations shared information with a circle of some 23 other local fishing associations. With experimentation and learning in each of these nodes, social networks located at multiple centers resembled polycentric governance. Shared knowledge through networking, combined with experimentation, created a diversity of experience and ideas that stimulated innovation, created feedback loops, and made it possible to deal with new problems [59].

The Swedish biosphere reserve (Kristianstads Vattenrike) case of Olsson et al. similarly shows a network approach to collaborative problem solving [52]. A new network was created over a period of time using some of the elements of three then-existing actor networks in the biosphere reserve: naturalist groups involved in bird conservation, groups concerned with cultural heritage, and those concerned with water quality. The new network was able to connect institutions and organizations, facilitating information flows, identifying knowledge gaps, and creating nodes of expertise relevant to ecosystem management. Olsson et al. emphasized the importance of leadership in the formation of vision and goals, and the role of bridging organizations that served to connect local actors with other organizational levels [52].

The network was a multilevel arrangement particularly appropriate for solving problems of complex adaptive systems: it enabled experimentation, knowledge generation, and social and institutional learning. It coordinated interactions among a range of actors at different levels, with a 
diversity of experiences and ideas for solving new problems. It nurtured sources for renewal and reorganization (in the resilience sense), and thus increased the capacity to deal with uncertainty and change. It also served to store social memory for ecosystem management, reviving and revitalizing memory in the reorganization phase of the adaptive cycle following change.

Collaborative networks are found in a variety of settings, for example in conservation-development projects [15]. Each of the ten community-based enterprises involved in conservation-development projects analyzed by Seixas and Berkes showed a network structure [61]. Networks involved communities, various levels of government agencies and a diversity of non-governmental organizations serving various support functions, with a total of some 10 to 15 partners per case among projects recognized for their success in combining local development with conservation. Partners provided a range of services and support functions: raising funds; institution-building; business networking and marketing; innovation and knowledge transfer; technical training; research; legal support; infrastructure; and community health and social services [15].

\section{Conclusions}

Environmental governance for sustainability, using principles and concepts from the broader area of commons, is a key part of addressing the 21st century challenge of planetary stewardship. Commons institutions are key players in enabling multilevel governance and local participation in decision-making. How do we bring governance closer to the people whose livelihoods are affected by these decisions? The mix of regimes to manage local, regional, and global commons cannot simply be the state-property and the private-property regime [22]. The mix needs to include common-property regimes, so that local people and institutions have a say in decisions and a chance to use their local and traditional knowledge to foster adaptive governance.

To recap the three-point argument to address the question of operationalizing adaptive governance, (1) people and environment need to be considered together as social-ecological systems used as the unit of analysis; (2) resilience, which deals with change in multilevel complex systems, is appropriate for the analysis of scale issues and the adaptive in adaptive governance; and (3) there is a need to foster collaborative approaches to improve learning for adaptive governance. I am suggesting that these concepts are part of the fundamentals of adaptive governance. All three are commonsense concepts and the terms come from everyday language, not from some esoteric or technical field. But operationalizing adaptive governance is something else again, and the devil is in the governance details.

First, using social-ecological systems as the unit of analysis is perhaps obvious, but it requires a shift in conventional governance practice, eliminating the divide between those governing and those being governed-and also eliminating artificial disciplinary divides. Adaptive governance scholarship arises largely out of the social-ecological resilience literature, but without doubt there still is progress to be made [7].

Second, adopting resilience thinking is another necessary challenge. Sustainability means not only achieving environmental, economic, and social objectives but also the ability to deal with uncertainty to adapt over time to unforeseen future changes. This requires attention to the multilevel nature of global issues. A number of planning approaches exist for adaptation under uncertainty [62]. The resilience approach seems to be one commonly used in a number of areas, from resource management to international security [40].

However, all concepts have limitations. Resilience is not the one-stop solution to all matters of change and adaptation. Like sustainability, resilience is a normative concept involving value judgments and social norms, and not all resilient systems (e.g., ongoing crime in urban core) are desirable [63]. Resilience thinking can be thought of as a supplement, and not a replacement, for the analysis of power and the historical and cultural contexts within which sustainability policies may be negotiated among stakeholders and levels of governance [44]. 
Third, perhaps the most important lesson of resilience thinking, and adaptive governance thinking in general, is the need for ways to improve learning and adaptive capacity. Social and institutional learning is a key issue and an area of dynamic research and application. Adaptive management has informed adaptive governance and adaptive co-management. Knowledge co- production and network learning approaches are but two of what must be a nearly unlimited number of possibilities to improve social learning for governance. The integration between social-ecological systems perspective and resilience thinking is excellent, but not with collaborative learning-and that is perhaps where further research, experimentation, and application might make a difference for operationalizing adaptive governance.

Much of the learning literature, with the exception of adaptive management, does not translate well at present into governance. Similarly, the literatures on social learning and transformative learning do not cross over much to governance. For example, the multilevel governance literature [6] overlaps very little with the co-management literature [34]. What moves and motivates people and communities? What are the conditions conducive to collective action? That is the science of the particular, and the experience in dealing with local institutions and the grassroots resides with the commons $[20,35]$ and the co-management literatures $[17,48]$. Assuming that adaptive governance is multilevel, the starting point cannot be the planetary level; it has to start from the ground up and be carried out simultaneously at all levels. Thus, operationalizing adaptive governance requires learning from, and improving on, practices of collaborative learning, with a focus on institutions at all levels from local to international.

Acknowledgments: My work has been supported by the Canada Research Chairs Program (http:/ /www.chairs.gc.ca). Conflicts of Interest: The author declares no conflict of interest.

\section{References}

1. Steffen, W.; Persson, A.; Deutsch, L.; Zalasiewicz, J.; Williams, M.; Richardson, K.; Crumley, C.; Critzen, P.; Schellnhuber, H.J.; Svedin, U.; et al. The Anthropocene: From global change to planetary stewardship. Ambio 2011, 40, 739-761. [PubMed]

2. Steffen, W.; Broadgate, W.; Deutsch, L.; Gaffney, O.; Ludwig, C. The trajectory of the Anthropocene: The Great Acceleration. Anthr. Rev. 2015, 2, 81-98. [CrossRef]

3. Lambin, E.F.; Meyfroidt, P. Global land use change, economic globalization, and the looming land scarcity. Proc. Natl. Acad. Sci. USA 2011, 108, 3465-3472. [CrossRef] [PubMed]

4. Millennium Ecosystem Assessment. Millennium Ecosystem Assessment Synthesis Report. Millennium Ecosystem Assessment; Island Press: Chicago, IL, USA, 2005.

5. Rockström, J.; Steffen, W.; Noone, K.; Persson, A.; Chapin, F.S.; Lambin, E.F.; Lenton, T.M.; Scheffer, M.; Folke, C.; Nykvist, B.; et al. A safe operating space for humanity. Nature 2009, 461, 472-475. [CrossRef] [PubMed]

6. Duit, A.; Galaz, V.; Eckerberg, K.; Ebbesson, J. Governance, complexity and resilience. Glob. Environ. Chang. 2010, 20, 363-368. [CrossRef]

7. Chaffin, B.C.; Gosnell, H.; Cosens, B.A. A decade of adaptive governance scholarship: Synthesis and future directions. Ecol. Soc. 2014, 19, 56. [CrossRef]

8. Levin, S.A. Fragile Dominion: Complexity and the Commons; Perseus Books: Reading, MA, USA, 1999.

9. Norberg, J.; Cumming, G.S. (Eds.) Complexity Theory for a Sustainable Future; Columbia University Press: New York, NY, USA, 2008.

10. Gunderson, L.H.; Holling, C.S. (Eds.) Panarchy: Understanding Transformations in Human and Natural Systems; Island Press: Washington, DC, USA, 2002.

11. Young, O.R. Beyond regulation: Innovative strategies for governing large complex systems. Sustainability 2017, 9, 938. [CrossRef] 
12. Gibson, C.; Ostrom, E.; Ahn, T.-K. The concept of scale and the human dimensions of global change: A survey. Ecol. Econ. 2000, 32, 217-239. [CrossRef]

13. Young, O.R. The Institutional Dimensions of Environmental Change: Fit, Interplay, and Scale; MIT Press: Cambridge, MA, USA, 2002.

14. Cash, D.W.; Adger, W.; Berkes, F.; Garden, P.; Lebel, L.; Olsson, P.; Pritchard, L.; Young, O. Scale and cross-scale dynamics: Governance and information in a multilevel world. Ecol. Soc. 2006, 11, 8. [CrossRef]

15. Berkes, F. Community-based conservation in a globalized world. Proc. Natl. Acad. Sci. USA 2007, 104, 15188-15193. [CrossRef] [PubMed]

16. Kocho-Schellenberg, J.-E.; Berkes, F. Tracking the development of co-management: Using network analysis in a case from the Canadian Arctic. Polar Rec. 2015, 51, 422-431. [CrossRef]

17. Chuenpagdee, R.; Jentoft, S. Step zero for fisheries co-management: What precedes implementation. Mar. Policy 2007, 31, 657-668. [CrossRef]

18. Berkes, F.; Colding, J.; Folke, C. (Eds.) Navigating Social-Ecological Systems: Building Resilience for Complexity and Change; Cambridge University Press: Cambridge, UK, 2003.

19. Ostrom, E.; Burger, J.; Field, C.B.; Norgaard, R.B.; Policansky, D. Revisiting the commons: Local lessons, global challenges. Science 1999, 284, 278-282. [CrossRef] [PubMed]

20. Ostrom, E. Governing the Commons: The Evolution of Institutions for Collective Action; Cambridge University Press: Cambridge, UK, 1990.

21. Stern, P.C. Design principles for global commons: Natural resources and emerging technologies. Int. J. Commons 2011, 5, 213-232. [CrossRef]

22. Dietz, T.; Ostrom, E.; Stern, P.C. The struggle to govern the commons. Science 2003, 302, 1907-1912. [CrossRef] [PubMed]

23. Folke, C.; Hahn, T.; Olsson, P.; Norberg, J. Adaptive governance of social-ecological systems. Annu. Rev. Environ. Resour. 2005, 30, 441-473. [CrossRef]

24. Folke, C.; Biggs, R.; Norström, A.V.; Reyers, B.; Rockström, J. Social-ecological resilience and biosphere-based sustainability science. Ecol. Soc. 2016, 21, 41. [CrossRef]

25. Ostrom, E. A general framework for analyzing sustainability of social-ecological systems. Science 2009, 325, 419-422. [CrossRef] [PubMed]

26. Díaz, S.; Demissew, S.; Carabias, J.; Joly, C.; Lonsdale, M.; Ash, N.; Larigauderie, A.; Adhikari, J.; Arico, S.; Báldi, A.; et al. The IPBES Conceptual Framework—Connecting nature and people. Curr. Opin. Environ. Sustain. 2015, 14, 1-16. [CrossRef]

27. Pascual, U.; Balvanera, P.; Díaz, S.; Pataki, G.; Roth, E.; Stenseke, M.; Watson, R.T.; Dessane, E.B.; Islar, M.; Kelemen, E.; et al. Valuing nature's contributions to people: The IPBES approach. Curr. Opin. Environ. Sustain. 2017, 26, 7-16. [CrossRef]

28. Berkes, F.; Folke, C. (Eds.) Linking Social and Ecological Systems; Cambridge University Press: Cambridge, UK, 1998.

29. Maclean, K.; Ross, H.; Cuthill, M.; Rist, P. Healthy country, healthy people: An Australian Aboriginal organisation's adaptive governance to enhance its social-ecological system. Geoforum 2013, 45, 94-105. [CrossRef]

30. Berkes, F.; Doubleday, N.C.; Cumming, G.S. Aldo Leopold's land health from a resilience point of view: Self-renewal capacity of social-ecological systems. EcoHealth 2012, 9, 278-287. [CrossRef] [PubMed]

31. Folke, C. Resilience: The emergence of a perspective for social-ecological systems analyses. Glob. Environ. Chang. 2006, 16, 253-267. [CrossRef]

32. Kooiman, J. Governing as Governance; Sage: London, UK, 2003.

33. Berkes, F.; Hughes, T.P.; Steneck, R.S.; Wilson, J.A.; Bellwood, D.R.; Crona, B.; Folke, C.; Gunderson, L.H.; Leslie, H.M.; Norberg, J.; et al. Globalization, roving bandits, and marine resources. Science 2006, 311, 1557-1558. [CrossRef] [PubMed]

34. Armitage, D.; Plummer, R.; Berkes, F.; Arthur, R.I.; Charles, A.T.; Davidson-Hunt, I.J.; Diduck, A.P.; Doubleday, N.C.; Johnson, D.S.; Marschke, M.; et al. Adaptive co-management for social-ecological complexity. Front. Ecol. Environ. 2009, 7, 95-102. [CrossRef]

35. Ostrom, E. Understanding Institutional Diversity; Princeton University Press: Princeton, NJ, USA, 2005. 
36. Young, O.R.; King, L.A.; Schroeder, H. (Eds.) Institutions and Environmental Change; MIT Press: Cambridge, MA, USA, 2008.

37. Potvin, C.; Aitken, S.; Anctil, F.; Bennett, E.; Berkes, F.; Bryne, C.; Creed, I.; Cunsolo Willox, A.; Dale, A.; de Lange, D.; et al. Acting on Climate Change: Solutions from Canadian Scholars; Sustainable Canada Dialogues: Montreal, QC, Canada, 2015.

38. Walker, B.; Holling, C.S.; Carpenter, S.R.; Kinzig, A. Resilience, adaptability and transformability in social-ecological systems. Ecol. Soc. 2004, 9, 5. [CrossRef]

39. Holling, C.S. Resilience and stability of ecological systems. Annu. Rev. Ecol. Syst. 1973, 4, 1-23. [CrossRef]

40. Berkes, F.; Ross, H. Community resilience: Toward an integrated approach. Soc. Natl. Resour. 2013, 26, 5-20. [CrossRef]

41. Armitage, D.; Charles, A.; Berkes, F. (Eds.) Governing the Coastal Commons. Communities, Resilience and Transformation; Earthscan/Routledge: London, UK; New York, NY, USA, 2017.

42. Brown, K. Resilience, Development and Global Change; Routledge: London, UK; New York, NY, USA, 2016.

43. Steneck, R.S.; Hughes, T.P.; Cinner, J.E.; Adger, W.N.; Arnold, S.N.; Berkes, F.; Boudreau, S.A.; Brown, K.; Folke, C.; Olsson, P.; et al. Creation of a gilded trap by the high economic value of the Maine lobster fishery. Conserv. Biol. 2011, 25, 904-912. [CrossRef] [PubMed]

44. Béné, C.; Newsham, A.; Davies, M.; Ulrichs, M.; Godfrey-Wood, R. Resilience, poverty and development. J. Int. Dev. 2014, 26, 598-623. [CrossRef]

45. Folke, C.; Carpenter, S.R.; Walker, B.; Scheffer, M.; Chapin, T.; Rockström, J. Resilience thinking: Integrating resilience, adaptability and transformability. Ecol. Soc. 2010, 15, 20. [CrossRef]

46. Berkes, F.; Ross, H. Panarchy and community resilience: Sustainability science and policy implications. Environ. Sci. Policy 2016, 61, 185-193. [CrossRef]

47. Brown, K.; Westaway, E. Agency, capacity, and resilience to environmental change: Lessons from human development, well-being, and disasters. Annu. Rev. Environ. Resour. 2011, 36, 321-342. [CrossRef]

48. Carlsson, L.; Berkes, F. Co-management: Concepts and methodological implications. J. Environ. Manag. 2005, 75, 65-76. [CrossRef] [PubMed]

49. Cumming, G.S. Risk mapping for avian influenza: A social-ecological problem. Ecol. Soc. 2010, 15, 32. [CrossRef]

50. Ostrom, E. Polycentric systems for coping with collective action and global environmental change. Glob. Environ. Chang. 2010, 20, 550-557. [CrossRef]

51. Biggs, R.; Schlüter, M.; Biggs, D.; Bohensky, E.L.; BurnSilver, S.; Cundill, G.; Dakos, V.; Daw, T.M.; Evans, L.S.; Kotschy, K.; et al. Toward principles for enhancing the resilience of ecosystem services. Annu. Rev. Environ. Resour. 2012, 37, 421-448. [CrossRef]

52. Olsson, P.; Folke, C.; Galaz, V.; Hahn, T.; Schultz, L. Enhancing the fit through adaptive co-management: Creating and maintaining bridging functions for matching scales in the Kristianstads Vattenrike Biosphere Reserve Sweden. Ecol. Soc. 2007, 12, 28. [CrossRef]

53. Ludwig, D. The era of management is over. Ecosystems 2001, 4, 758-764. [CrossRef]

54. Holling, C.S.; Meffe, G.K. Command and control and the pathology of natural resource management. Conserv. Biol. 1996, 10, 328-337. [CrossRef]

55. Berkes, F. Evolution of co-management: Role of knowledge generation, bridging organizations and social learning. J. Environ. Manag. 2009, 90, 1692-1702. [CrossRef] [PubMed]

56. Kates, R.W.; Clark, W.C.; Corell, R.; Hall, J.M.; Jaeger, C.C.; Lowe, I.; McCarthy, J.J.; Schellnhuber, H.J.; Bolin, B.; Dickson, N.M.; et al. Sustainability science. Science 2001, 292, 641-642. [CrossRef] [PubMed]

57. Armitage, D.; Berkes, F.; Dale, A.; Kocho-Schellenberg, E.; Patton, E. Co-management and the co-production of knowledge: Learning to adapt in Canada's Arctic. Glob. Environ. Chang. 2011, 21, 995-1004. [CrossRef]

58. Tengö, M.; Brondizio, E.S.; Elmqvist, T.; Malmer, P.; Spierenburg, M. Connecting diverse knowledge systems for enhanced ecosystem governance: The multiple evidence base approach. Ambio 2014, 43, 579-591. [CrossRef] [PubMed]

59. Olsson, P.; Folke, C.; Berkes, F. Adaptive co-management for building resilience in social- ecological systems. Environ. Manag. 2004, 34, 75-90. [CrossRef] [PubMed] 
60. Olsson, P.; Folke, C. Local ecological knowledge and institutional dynamics for ecosystem management. A study of Lake Racken watershed, Sweden. Ecosystems 2001, 4, 85-104. [CrossRef]

61. Seixas, C.S.; Berkes, F. Community-based enterprises: The significance of partnerships and institutional linkages. Int. J. Commons 2010, 4, 183-212. [CrossRef]

62. Walker, W.E.; Haasnoot, M.; Kwakkel, J.H. Adapt or perish: A review of planning approaches for adaptation under deep uncertainty. Sustainability 2013, 5, 955-979. [CrossRef]

63. Norton, B. Sustainability: A Philosophy of Adaptive Ecosystem Management; University of Chicago Press: Chicago, IL, USA, 2005.

(C) 2017 by the author. Licensee MDPI, Basel, Switzerland. This article is an open access article distributed under the terms and conditions of the Creative Commons Attribution (CC BY) license (http://creativecommons.org/licenses/by/4.0/). 